\title{
Determinants of Banks' Costumer's Intention to adopt Internet Banking Services in Yemen: Using the Unified Theory of Acceptance and Use of Technology (UTAUT)
}

\author{
Nabil Hussein Al-Fahim* \\ Faculty of Information and Communication Technology \\ International Islamic University \\ Malaysia \\ Correspondence: \\ Correspondence: nalfaheem@gmail.com \\ Rawad Abdulgafor \\ Faculty of Information and Communication Technology \\ International Islamic Universitiy \\ Malaysia, Kuala Lumpure, 53100 \\ Correspondence: rawad@iium.edu.my \\ Edres Hamood Qaid \\ Faculty of Business Management \\ Limkokwing University \\ Malaysia, Kuala Lumpure, 53100 \\ edreshamood92@gmail.com
}

\begin{abstract}
Researches on Internet Banking (IB) in the context of Yemen is still lacking which creates the necessity to conduct such a study to investigate the adoption level of IB services. Thus, this study aims at examining and investigating the factors influencing the adoption of IB among banks' customers in Yemen through the use of the UTAUT theory. The framework of this study comprises one endogenous variable the intentions to use IB services) and five exogenous variables in which the exogenous variables consist of effort expectancy, performance expectancy, trust, social influence, and awareness. The identified moderators in this study are the role of age and experience that influence the intentions of banks' customers to use and adopt IB services. The survey questionnaire was distributed to a sample that consists of 354 bank customers and the returned data was screened and then analyzed using structural equation modeling (SEM) to investigate the correlations and relationship among variables. Meanwhile, the indirect impact of the moderating variables was investigated using multiple-group analysis (MGA). The results of this study revealed that effort expectancy, performance expectancy, awareness, and trust have a significantly positive impact on customers' intention to adopt IB services in Yemen. However, the social influence showed
\end{abstract}

no significant effect on IB services. Moreover, the age and experience variables showed a moderating impact on customers' intention to adopt IB services in Yemen.

Keywords - Internet Banking, UTAUT Factors, ecommerce, Yemen

\section{INTRODUCTION}

Internet banking Services (IBS) is essential for both customers and bank. IBS is beneficial for banks in terms of cost-effectiveness, efficiency, improve reputation, reach a wide range of populations, provide unlimited distribution networks which improve the competitive advantages to banks, and offer excellent banking experience (Nasri, 2011; Khrerwesh, 2011). The use of IB technology allows banks to offer excellent and high-value- financial and banking services at lower costs and allow building strong customer and bank relationships (Al-Sukkar \& Hasan, 2005).

The Yemeni government has established various measures to improve the sustainability of the economy and the development growth of the county and one of the major key developments to transfer Yemen into a digitalized country is the use and adoption of IB services by populations. The IB services adoption is an excellent economy facilitator as it improves the banking experiences and strengthens the relationship between people and their banks. However, in the context of Yemen, there is limited data on to what extent does IB influences the economy. Therefore, this study aims at 
identifying the influences of IB services adoption and the parameters that impact customers to use online banking in Yemen as well as to comprehends the current and futuristic perceptions of Yemeni people towards the IB services. This study motivation was selected from the literature especially a study by Illuminas (2006) and Net Impact Canada 2006 and it is aimed through this research that the findings would provide important knowledge for further studies particularly in Yemen. Moreover, the findings will be useful for decisionmakers and banks to understand the factors influencing their customers' intention towards the adoption of IB technology. Toward this end, the data was collected from banks' customers in the Yemeni Capital city Sanaa from a total of 354 bank customers.

The IB technology is still new in Yemen, and it is not widely used and accepted by customers, retails, and banks, which indeed is influenced by the cultural settings of Yemeni society which favor face-to-face banking services. Despite all that, limited studies have been carried out in the context of Yemen to examine the factors influencing the adoption of IB services among bank's customers (Riffai, Kevin, Edgar, 2011).

Furthermore, Jayawrdhena and Foly (2000) suggested that IB services provide important values to customers including lower costs to use IB online banking, ease of use and comforters when conducting transactions at any time of the day and night and enhances the banking speeds and improve customers -banks relationships and trust. The IB technology also improves banks' competitive advantage in the market as it increases financial dealings speed, offers innovative technologies and services to customers at a lower cost which is essential to the sustainability of banks in this changing digitalized world (Jeeven, 2000).

However, despite all the benefits, many Yemeni customers still afraid of embracing these technologies provided by banks which creates a need to investigate the factors influencing customers intentions to help build up trust and awareness of customers in Yemen towards the IB services (Parker and Castelman 2007; Shiels et al 2003).

Therefore, this research aims at examining the factors that impact the adoption of the Yemeni population of IB services and thus extends the body of knowledge in this field by providing new findings from a developing country known as Yemen.

The objectives of the study:

- To measure the UTAUT variables (effort expectancy, performance expectancy, trust, social influence, and awareness) that impact the BI adoption by bank customers in Yemen.

- To examine the role age and experience of customers as moderators in the behaviour intentions towards IB adoption by banks customers in Yemen.

\section{LITERATURE REVIEW}

\section{A. An Overview of banking sector in Yemen}

According to the data released by the Central Bank of Yemen (2009), a total of 17 commercial banks are exist in the country in which six of these banks are branches of foreign banks. As the IB is a new technology, there are only four banks in Yemen that currently provide online IB services which is not surprising at all given that the cultural settings of Yemeni society favor face-to-face dealings. According to $\mathrm{Al}$ and Tatnall (2007), the banking industry in Yemen operates cautiously and slowly trying to catch up with online electronic services to suit the population's intentions. This indeed raised several questions among them about what and why factors impact such decisions of the banking industry in Yemen. In answering these questions, one must comprehend the development of ICT in Yemen in order to fully understands the progress of online technologies in Yemen (Nour, 2002). Consequently, this study aims to combine the factors of the technology adoption and intention to use in order to identify the factors that influence the use of IB services within a Yemeni context and use the existing models to draw conclusive remarks on the improvements of IB technology use in Yemeni.

\section{B. Internet banking adoption}

The Internet banking adoption (IBA) has been described as the use of clients to several provided online services such as loan applications, transactions, balance checking, shopping, and etc (Shih \& Fang, 2004).

\section{Unified Theory of Acceptance and Use of Technology (UTAUT)}

UTAUT is a very important theory in technology use and adoption which was first introduced in the last two decades in 2003 by Venkatesh et al. (Venkatesh et al., 2003). It is an excellent model that examines user intentions to use and adopt certain technology (Alshehri, Drew \& AlGhamdi, 2013). Compared to other technology theories such as TPN, TAM, TRA, TAM2, MM, and MPCU model, the UTAUT is superior in providing important findings that explain the factors hindering or allowing the usage and continuous usage of certain technology. In fact, UTAUT is comprised of several models mentioned above and it allows predicting and explaining user's behaviour towards the use of technology and it has four variables namely the effort expectancy, performance expectancy, facilitating conditions, and trusts (Alshehri, Drew \& AlGhamdi, 2013) (Venkatesh et al., 2003). In addition, four mediators are also found such as age, gender, the voluntariness of use, and experience when examining the intention behaviour of individuals.

A UTAU theory explains and predicts how certain factors influence the intention to adopt and use technology particularly in terms of perceived ease of use, usefulness, and intentions which are mediated by age, gender, and experience (Alshehri, Drew \& AlGhamdi, 2013). For example, age and gender contribute to the difference in the strength between perceived usefulness and intention to use which is essential to examine both males and females (Venkatesh et al., 2003).

\section{Behavior Intention towards Internet Banking Adoption (Dependent Variable)}

The Internet banking adoption (IBA) has been described as the use of clients to several provided online services such as loan applications, transactions, balance checking, shopping, and etc (Shih \& Fang, 2004).

In previous years, IB is a well-studied area especially in developed countries in which several notions and insight have been enriched the literature especially in terms of illustrating the effects of technology factors in determining the intention 
to use and adopt IB technology (Abbad, 2013 Kesharwani \& Tripathy, 2012). The majority of previous studies have utilized the TOE framework to investigate the impact of various factors on the behaviour and attitude to adopt technology (Chiou and Shen, 2012).

\section{E. Factors Influencing Internet Banking Adoption (Independent Variables)}

The main goal of this study is to understand banks customers' IB adoption through investigating its key factors using the UTAUT framework. These factors include (performance and effort expectancy) explain in our dependent variable BI towards IB adoption.

The literature identifies several important models used to examine the behaviour of individuals to use and adopt certain technologies such as the acceptance model (TAM), the UTAUT, and the innovation diffusion theory (IDT) (Shaikh and Karjaluoto, 2015). Among these theories, the UTAUT has been widely investigated and considered as a comprehensive model that predicts and illustrates user acceptance and adoption of certain technologies (Martins et al., 2014). Since its introduction in 2003 by Venkatesh et al., it has been implemented widely in information systems and social science studies and it has four constructs as mentioned earlier. Throughout the years the UTAUT has witnessed several modifications as to introduce new constructs into the original theory such as trust, awareness, and social influence and etc. (Yousafzai et al., 2010).

\section{1) Performance Expectancy (PE) and IB Adoption}

$\mathrm{PE}$ represents the perceptions of the user to certain improvements of the technology in terms of the performance such as the banking tasks efficiency performance and the ability of IB to carry out such as with improved performance ability (Venkatesh et al., 2003).

Zuiderwijk, Janssen, and Dwivedi (2015) utilized a modified UTUAT theory to examine the predictors that impact the use and acceptance of open data technology. They found that the PE is an excellent explanatory factor that influences the acceptance and use of such technology and is positively related to the intention of an individual to use the provided technology. Indeed, PE is one of the most important factors to illustrates the intention to use and adopt IB services. Similar findings were obtained by Hew et a., (2015) and Der and Mutlu (2015). Al-Qeisi et. al. (2014) found an indirect impact of PE on IB use by investigating the website design variable which impacts the perceptions of people to use IB technology. It is thus required by banks to establish a connection with their customers and promote the IB technology ease of use, usefulness, image, and value which make people aware of the PE of the given technology (Irfan et al.; 2013).

\section{2) Effort Expectancy (EE) and IB Adoption}

EP is illustrated as the ease of use of the given technology or system (Venkatesh et al., 2003). People prefer to use a technology or a system that is less complex and would likely to recommend such technology to their relatives and friends. As demonstrated by previous studies, the EE is an excellent variable which influences the intention of an individual to accept and use IB technology (Venkatesh et al., 2003; Venkatesh \& Zhang, 2010). Thus, hypothesized the EE is one of the key variables which influences the acceptance and adoption of IB.
De Sena Abrahaoa, Moriguchi, and Andrade (2016) found that the EP factor is one of the key variables that influence the intention of mobile payment users. Tsourela and Roumeliotis (2015) revealed a strong positive relationship between EE and BI services. Awwad and Al-Majali (2015) empirically found that the EE an important exploratory variable of BI services in universities in Jordan. Teo and Noyes' (2014) found that EE has a positive impact on the adoption of BI among trainee teachers.

\section{3) Social Influence (SI) and IB Adoption}

SI refers to the perceptions of people with respect to their societies, friends, or relatives whether or not they should perform the behaviour in question as reported by (Shan et al.,2013). Social influence can also be defined as the extent to which an induvial perceives that important others believe she/he should accept and adopt technology or system or comply with other people's expectations (Chou and Katelin, 2016). SI in the context of IB services and adoption refers to the degree to which bank's customers perceives that important other believe they should use and adopt online BI services (Venkatesh et al., 2012).

\section{4) Perceived Trust and IB Adoption}

Trust in the system refers to the individual's uncertainty and dependency when involving in online transactions. It has been established in developing countries that virtual banking is likely to influence by the trust of uncertainties especially in the traditional settings (Rotchankitumnuai \& Speece, 2007). Trust has been known as the strategic factor in previous studies as it is one of the essential factors that determine the intention of people to use marking technologies (Haque et al., 2009).

According to Montazemi and Qahri-Saremi (2015) trust is one of the key factors that determine people's intention to use technology and without it other factors are ineffective. They concluded that trust is a prominent factor in IB technology adoption as it impacts individual intention to use online banking which means that the trust must be built between bank industry and population through introducing security and online safety measures and make people aware of such innovating security settings. This indeed will improve the trust factor and increase their adoption to use IB services. Through the literature, previous studies have suggested that trust is an important variable that be must be taken seriously when introducing new technology of system to people and it is an important factor that determines the people rejection of adoption of IB services (Gupta, and Kamilla, 2014). Trust indeed has a positive impact on technology acceptance and adoption. It influences people intention and behaviour to embrace new technology or system especially BI services which involves virtual banking.

\section{5) Awareness and IB Adoption}

According to Rogers (1983) the awareness of innovation refers to the extent to which individuals are exposed to the existence of innovation and the likelihood of how the innovations function. Meanwhile, Sathye (1999) defined awareness of innovation as the perceptions of individuals or customers of certain services or not and argued that the low awareness certainly impacts the adoption of IB. Similarly, AlMajali (2011) indicated that the awareness of technology is an essential factor that determines the level of acceptance and adoption among people (users). Suzanne Harrison, Peter Onyia, and K. Tagg, (2014) argued that the customers who have prior experiences on how to use computers and the 
internet are and are aware of BI benefits would be more willing to adopt IB those with less awareness of the benefit and the system.

According to Ramsey, Ibboston, Bell, and Gary (2003) the awareness and knowledge of the system benefits among small and medium enterprises have a positive impact on their desire to accept and adopt e-businesses. Besides, Lacovou, Benbasat, and Dexter (2005) found that the low awareness of the system or technology and its benefits causes low acceptance and adoption level of e-business and they indicated that the lack of understanding of the technology can adversely influence its adoption. Huy, Rowe, Truex, and Huynh (2012) found that the understand of IT and Internet technologies have enabled the adoption of e-commerce as the knowledge of the technology and its benefits as well as experience in using the Internet positively influenced the technology adoption.

\section{F. Research Moel Justification (UTAUT) for Customers}

UTAUT is modified to cope with the technology being investigated (BI) and the environment where it is used in Venkatesh et al. (2003). This study would choose two variables (PE and EE) from the UTAUT model since other variables such as facilitating conditions and social influence are not required since Internet banking platforms can be available and accessible to all participants' customers.

This study also added some related constructs to be used in the UTAUT framework which have been reported in previous similar studies in different contexts such as trust, and awareness of technology. Therefore, in this study, the UTAUT context includes PE, EE, SI, trust, and awareness. The study chooses these elements in reference to previous studies such as (Ammar, 2017, Muhayiddin, 2014).

\section{METHODOLOGY}

The quantitative research design was utilized in this study as it is the most appropriate to the given nature of the study as this study hopes to assess banks' customers' intention to adopt IB by using hypothesis testing which requires a quantitative approach to tackle and analyze with the data.

Therefore, the self-administered survey method was used to collect the data by utilizing the convenience sampling method which suits the nature of the study.

\section{A. Questionnaire design}

The questionnaire design was carried out using the above union constructs and was self-administered using convenience sampling in order to collect the relevant primary information required for further analysis. The survey questionnaires comprise two parts: the first part seeks to gather the demographic information of banks' customers while the second part seeks to gather the data about the constructs of this study which are (1) IBA, (2) PE (3) EE, (4) SI, (5) trust, (6) awareness. Note that the first variable (1) is the endogenous variable meanwhile, the exogenous variables are the factors $(2-6)$.

Out of a total of 450 distributed survey questionnaires on the banks' customers, almost $80 \%$ were returned which represented 380 questionnaires. There are 12 responses that were discarded because of missing data issues. There are also 14 cases which were outliers. Therefore, the total usable questionnaires are 354 which contributed to total a response rate of $84 \%$ which is considered sufficient to carry out this study. According to Hair et al., (2010), the missing data could be replaced by the mean values which is equivalent to $5 \%$ and less of the total needed data.

\section{ANALYSIS AND RESULTS}

\section{A. Descriptive Statistics for constructs}

Table 1 shows the analyses of the results of the descriptive statistics for the constructs which indicate that trust and IS have the largest mean that reached up to 4.065 and 4.0469 out of a maximum 5 respectively, it's making up to $81 \%$. This is seconded by effort expectancy and awareness at 3.723 and 3.631 made up $74 \%$ and $72 \%$ respectively.

In the other hand, internet banking recorded the lowest mean with 3.219 taking approximately $64 \%$, and out of a max 5 $(75 \%)$ the average overall was 3.77 . The obtained S.D. values of the factors range from 0.972 to 1.164 which indicates acceptable variability among the data set.

The standard deviations (S.D) range for all of the variables from 0.972 to 1.164 , which reflects the existence of considerable acceptable variability within the data set.

Table 1: Descriptive analyses of the constructs

\begin{tabular}{cccc}
\hline Variables & Code & Mean & S.D. \\
\hline IB & IB & 3.2192 & .97224 \\
Expectancy & EP & 3.4757 & 1.14309 \\
Performance & & & \\
Effort Expectancy & EE & 3.6316 & 1.16479 \\
Social Influence & SI & 4.0469 & .73869 \\
Trust & TR & 4.0645 & .77921 \\
Awareness & AW & 3.7232 & .97224 \\
Overall & & 3.772 & .99340 \\
\hline
\end{tabular}

\section{B. Reliability and composite reliability}

Reliability measurement is very important as it allows determining the consistency in the measurements of the variables (Kim \& Cha, 2002). In general, the reliability of an instrument must be higher than the accepted values which are 0.60 (Hair et al., 2006; Sekaran, 2003). Two important reliability tests were utilized in this study which are Cronbach's alpha and composite reliability (CR). The results indicated that the values of Cronbach's alpha range from 0.840 to 0.932 meanwhile the results of CR ranged from 0.858 to 0.940 as shown in Table 2. The results of the reliability in this study are greater than the 0.6 recommended value stated by previous scholars which shows the reliability of the measurements of the variables in this study.

Table 2: CR and Cronbach's Alpha for the variables.

\begin{tabular}{|cccc}
\hline Variables & $\begin{array}{c}\text { No. } \\
\text { of } \\
\text { Item } \\
\text { s }\end{array}$ & $\begin{array}{c}\text { Cronbac } \\
\text { h's } \\
\text { alpha }\end{array}$ & CR \\
\hline $\begin{array}{c}\text { Internet banking } \\
\text { adoption }\end{array}$ & 5 & 0.877 & 0.872 \\
$\begin{array}{c}\text { Expectancy } \\
\text { Performance }\end{array}$ & 4 & 0.918 & 0.914 \\
$\quad$ Effort & 5 & 0.932 & 0.940 \\
$\begin{array}{c}\text { Expectancy } \\
\text { Social Influence }\end{array}$ & 4 & 0.892 & 0.902 \\
\hline Trust & 4 & 0.855 & 0.886 \\
\hline
\end{tabular}




$\begin{array}{llll}\text { Awareness } & 4 & 0.840 & 0.858\end{array}$

Most of the indicators showed obtaining of a good fit as per the recommended values which this study uses (Hair et al., 2010). The chi-square ratio to the degree of freedom $(\chi 2)$ was found to be 1.735 in the final model which is less than 5 and that means the model presented has a good fit and the RMSEA is 0.046 (less than 0.08) which further affirms the good fit of the model (Hair et al., 2006). In addition, the GOF measure indicated that the model to the data as such $(\mathrm{CFI}=0.968$, IFI= 0.969 , TLI $=0.958$ ) which means this study used a good fit to the data model (Schumacker \& Lomax, 2004; Lee and Kim, 2007). Fig.1 depicts the model's measurement for the variables utilized in this study.

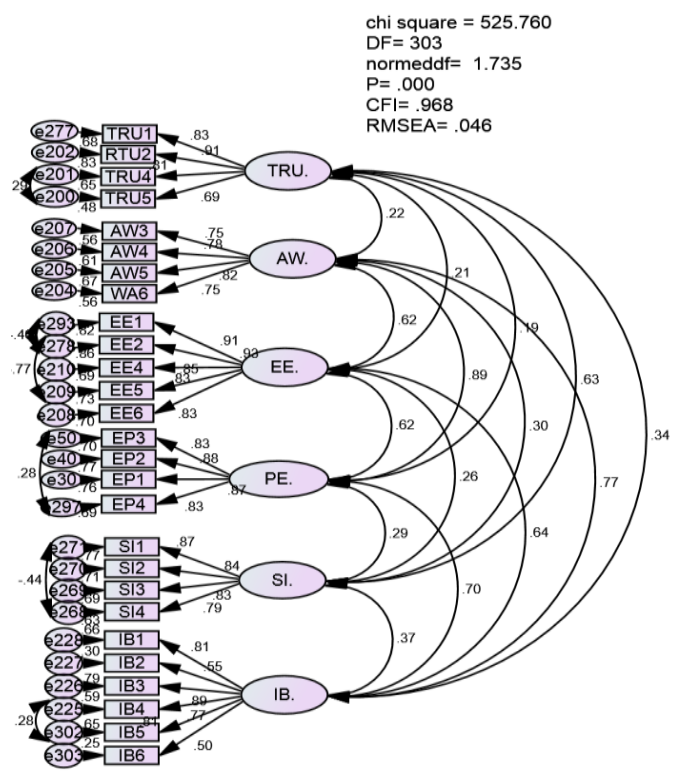

Fig. 1. Measurement Model with Standardized Estimated

\section{Assessment of Measurement Model}

\section{1) Convergent validity}

After the modification of the measurement model findings reveal all the constructs indicated had greater loadings than 0.50 , which were higher than the accepted value. Thus, the element loading for each item has achieved more than 0.50 which is higher than the accepted 0.3 value (Hair, et. al., 2006). As such, findings provide evidence that convergent are valid. Hence, all indicators in this study are related to their respective variables, and thus there is evidence of satisfactory for the convergent validity of the proposed model in this study and ranged from 0.507 to 0.914 as shown in Figure 1.

\section{2) Discriminant Validity}

Hair et al., (2010) indicated that the discriminant validity is an essential test which can be tested by employing the square average variance that is extracted for every variable against the correlation coefficient among variable and other variables within the same model. Therefore, each variable would have an adequate discriminant validity when the value of AVE exceeds the value of correlation among variables (Fronell \& Larcker, 1981). Based on Table 3, the AVE values for each variable in this study are more than the correlation square of the provided variable with any other variable (AVE> correlation square).

Table 3: UTAUT discriminant validity for latent variables

\begin{tabular}{cccccccc}
\hline & AVE & AW. & PE. & TRU. & EE. & IB. & SI. \\
\hline AW. & 0.765 & 0.875 & & & & & \\
PE. & 0.727 & 0.885 & 0.853 & & & & \\
TRU. & 0.662 & 0.216 & 0.189 & 0.813 & & & \\
EE. & 0.760 & 0.619 & 0.624 & 0.208 & 0.872 & & \\
IB. & 0.541 & 0.770 & 0.698 & 0.336 & 0.636 & 0.736 & \\
SI. & 0.697 & 0.300 & 0.294 & 0.629 & 0.261 & 0.369 & 0.835 \\
\hline
\end{tabular}

\section{Structural Model}

The findings of the structural model showed that the model first indicators such as the value of the normed $\chi 2$ (ratio value) is 2.910 that is less than 5 , which indicates sufficient fit. In addition, CFI $=0.915, \mathrm{TLI}=0.908$ and IFI $=0.916$, which further affirms the good fit of the model to data. Moreover, the parsimonious index (RMSEA) provided excellent results as RMSEA $=0.074$, which is less than the recommended value (Hair et al. 1998; 2006). Fig. 2 shows the findings of the structural model (Goodness-of-Fit Indices).

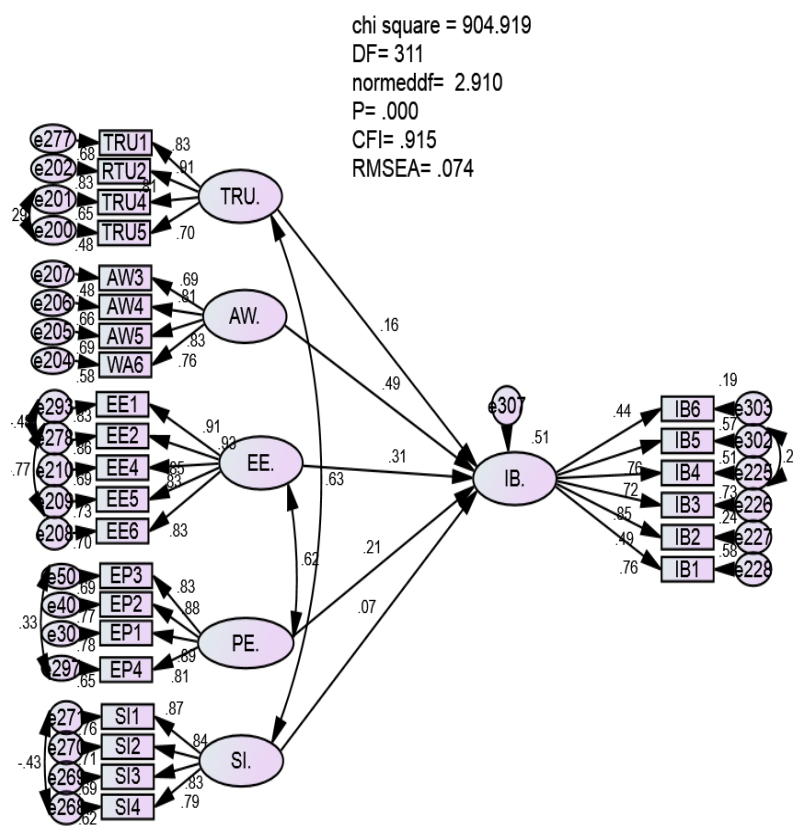

Fig. 2. Structural Model with Standardized Estimated Model

\section{E. Hypotheses Results for UTAUT Model}

There are five main direct hypotheses related to the aim of this study which were tested by the empirical study. Further, the hypotheses were assessed by the use of the SEM via AMOS as explained in Fig. 2 and 4. The structural model evaluation is further depicted in Table 4 which gives the dictation of the hypothesis's tests.

The findings showed that expectancy performance bear a significant and positive effect on the IB adoption among banks' customers $(\beta=0.207 ; C . R=3.315 ; P=0.000)$. As such, $\mathrm{H} 1$ is accepted. And also effort expectancy had a significant 
and positive effect on internet banking adoption $(\beta=0.311$; C. $\mathrm{R}=5.047 ; \mathrm{P}=0.000$ ). Thus, $\mathrm{H} 2$ is supported. On the other hand, social influence was a significant and positive impact on Internet banking adoption $(\beta=0.068 ; C . R=1.088 ; P=0.277)$ but awareness had a strongly significant on internet banking adoption among banks customers in Yemen $(\beta=0.493$; $C . R=$ 8.391; $\mathrm{P}=0.000)$. Furthermore, trust has a significantly positive effect on Internet banking adoption $(\beta=0.162 ; \mathrm{C} . \mathrm{R}=$ 2.529; $\mathrm{P}=0.011)$. Therefore, $\mathrm{H} 4$ and H5 are supported. Table 4 presents hypotheses results for UTAUT Model

\section{F. Moderating Factor Hypothesis (Age) Moderating effect} of Age and UTAUT factors and IB adoption among bank Customers

\section{A. Banking adoption among bank customers.}

To effectively investigate the effect of the age mediating variable, simultaneous analysis of size on two groups (less than 40 years and 40 years and above) was conducted. In this case, the coefficient path $(\mathrm{PE} \longrightarrow \mathrm{IB}$ ) was constrained to be equal to each other across the groups (less than $40=\mathrm{n} 1=197$ ) and $(40$ and above $=\mathrm{n} 2=157)$. Table 5 shows the $\mathrm{z}$-score $=$ $-2.468 * *$ for high age as a significant factor because the $\mathrm{p}$ value by high age group $(\beta=0.334, p=0.000)$ were higher than the low age group $(\beta=0.093, p=0.108)$. Thus, age mediates the relationship between performance expectancy and Internet banking adoption for the 40 years and above group. Hypothesis H6a is accepted.

Furthermore, the path coefficient (AW IB) constrained to be equal to each other across the groups and zscour $=2.717^{* *}$ (significant effect) by low age (less than 40 years) because of the coefficient path and $p$-value by low age group $(\beta=0.430, p=0.000)$ were much more than the high age group (40 years and above), $(\beta=0.161, p=0.008)$. Therefore, age moderates the relationship between awareness and Internet banking adoption for the low age group by banks' customers in Yemen. Hypotheses H6a and H6d are accepted.

In contrast, age has shown no moderation on the relationship between EE, IS, trust, and Internet banking adoption among customers due to $\mathrm{z}$-scour was not significant (0452, -0.248 , and -0.458 ) respectively. Therefore, H6b, H6c, and H6e are unsupported.

\section{G. Moderating Factor Hypothesis (Experience)Moderating effect of Experience between UTAUT Factors and Internet Banking Adoption among banks customers.}

To test the experience invariance, a simultaneous analysis of size that is based on two groups (IB users and non-users IB) was carried out. In this case, the path coefficient (EE IB) was constrained to be equal to each other across the groups (users $=\mathrm{n} 1=112$ ) and (non-users $=\mathrm{n} 2=197)$. Table 6 presents that $\mathrm{z}$-score $=2.723^{* *}$ ( significant effect) for users due to the path coefficient and $p$-value by IB users group $(\beta=0.411, p=$ $0.000)$ were non-users group $(\beta=0.014, p=0.014)$. Therefore, experience moderates the relationship between effort expectancy and Internet banking adoption for users IB group. So, Hypothesis H7c and H7d are accepted.

In contrast, the experience did not moderate the relationship between performance expectancy, social influence, and trust and Internet banking adoption among banks' customers in Yemen because z-scour was not significant $(0.492,-0.824$, and 0.518$)$ respectively. As such, $\mathrm{Ha}, \mathrm{Hb}$, and $\mathrm{He}$ is rejected.

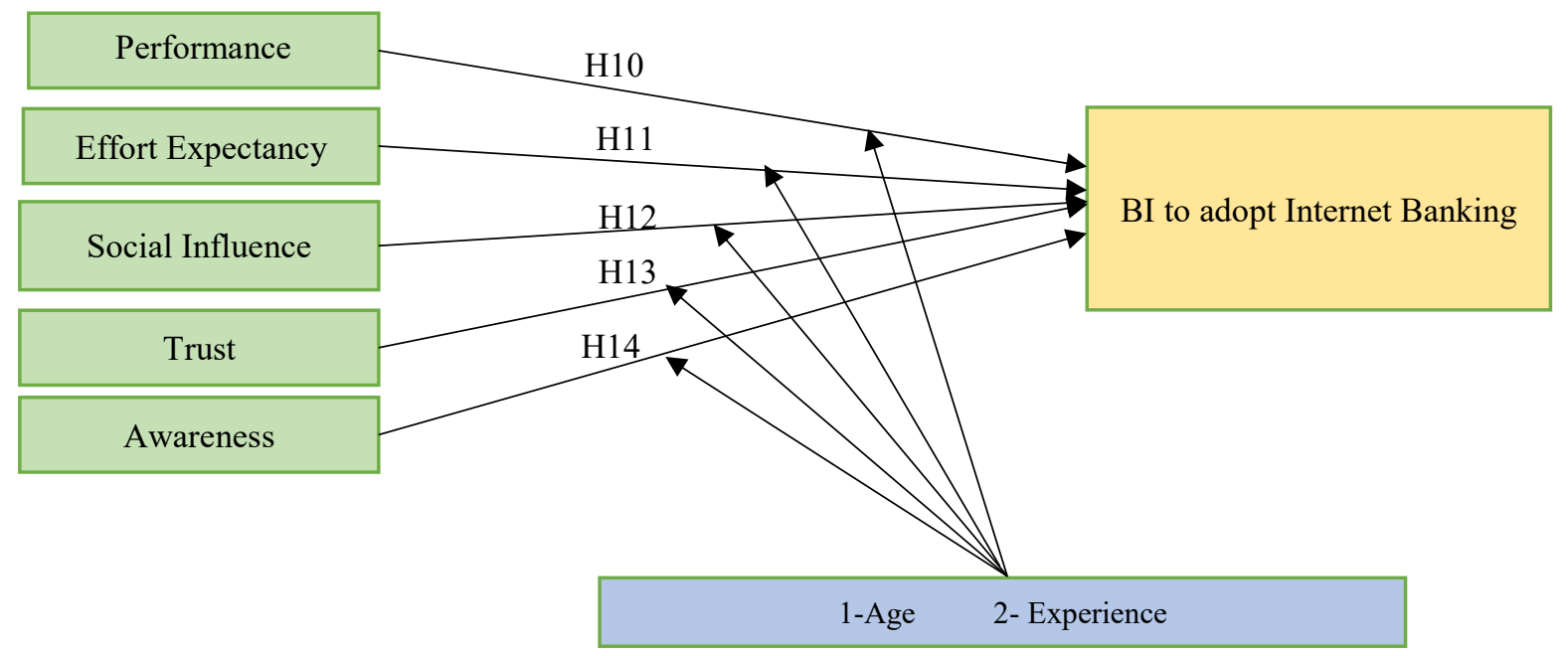

Fig. 3. Conceptual Framework (UTAUT) and Hypotheses Model for Customers

Table 4: Hypotheses results for the UTAUT model (Costumers)

\begin{tabular}{|c|c|c|c|c|c|c|}
\hline $\begin{array}{l}\text { Hypothes } \\
\text { es }\end{array}$ & $\begin{array}{l}\text { Exogenous } \\
\text { Variables }\end{array}$ & $\begin{array}{l}\text { Endogenous } \\
\text { Variable }\end{array}$ & Std. Estimates & C.R & P-Value & Result \\
\hline H1 & EP & $\Rightarrow \quad$ IB & 0.207 & 3.315 & 0.000 & Accepted \\
\hline $\mathrm{H} 2$ & $\mathbf{E E}$ & IB & 0.311 & 5.047 & 0.000 & Accepted \\
\hline H3 & SI & IB & 0.068 & 1.088 & 0.277 & Rejected \\
\hline H4 & TRU & IB & 0.162 & 2.529 & 0.011 & Accepted \\
\hline H5 & $\mathbf{A W}$ & IB & 0.493 & 8.391 & 0.000 & Accepted \\
\hline
\end{tabular}

Table 5: Results of Moderating Effect- Age 


\begin{tabular}{|c|c|c|c|c|c|c|c|c|c|}
\hline \multirow[t]{2}{*}{ Hypotheses } & \multicolumn{3}{|c|}{ Variables } & \multicolumn{2}{|c|}{$\begin{array}{l}40 \text { Years and } \\
\text { above } \\
157\end{array}$} & \multicolumn{2}{|c|}{$\begin{array}{l}\text { Less than } 40 \\
\text { Years (197) }\end{array}$} & \multirow[b]{2}{*}{ Exg. } & \multirow{2}{*}{$\begin{array}{c}\text { Hypotheses } \\
\text { Estimate } \\
\end{array}$} \\
\hline & End. & & Exg. & Estimate & p-value & End. & & & \\
\hline H6a & IB. & $<-$ & PE. & 0.334 & H6a & IB. & $<--$ & PE. & 0.334 \\
\hline H6b & IB. & $<-$ & SI. & -0.002 & H6b & IB. & $<--$ & SI. & -0.002 \\
\hline H6c & IB. & $<-$ & EE. & 0.239 & H6c & IB. & $<-$ & EE. & 0.239 \\
\hline H6d & IB. & $<-$ & AW. & 0.161 & H6d & IB. & $<--$ & AW. & 0.161 \\
\hline H6e & IB. & $<-$ & TRU. & 0.213 & H6e & IB. & $<--$ & TRU. & 0.213 \\
\hline
\end{tabular}

Table 6: Results of Moderating Effect- Experience

\begin{tabular}{|c|c|c|c|c|c|c|c|c|c|}
\hline Hypotheses & \multicolumn{3}{|c|}{ Variables } & \multicolumn{2}{c|}{$\begin{array}{c}\text { Non-users IB } \\
(242)\end{array}$} & \multicolumn{2}{c|}{ Users IB (112) } & Result & \\
\cline { 2 - 10 } & End. & & Exg. & Estimate & $\begin{array}{c}\text { p- } \\
\text { value }\end{array}$ & Estimate & p-value & Z-score & \\
\hline H7a & IB. & $\begin{array}{c}<- \\
-\end{array}$ & PE. & 0.127 & 0.058 & 0.17 & 0.002 & 0.492 & Rejected \\
\hline H7b & IB. & $\begin{array}{c}<- \\
-\end{array}$ & SI. & 0.094 & 0.172 & -0.002 & 0.979 & -0.824 & Rejected \\
\hline H7c & IB. & $\begin{array}{c}<-- \\
-\end{array}$ & EE. & 0.152 & 0.014 & 0.411 & $* * *$ & $2.723^{* * *}$ & Accepted \\
\hline H7d & IB. & $\begin{array}{c}<-- \\
-\end{array}$ & AW. & 0.274 & $* * *$ & 0.441 & $* * *$ & $-1.913^{*}$ & Accepted \\
\hline H7e & IB. & $\begin{array}{c}<-- \\
-\end{array}$ & TRU. & 0.184 & 0.026 & 0.252 & 0.015 & 0.518 & Rejected \\
\hline
\end{tabular}

\section{DISCUSSION AND CONCLUSION}

This study examines the variables of IB adoption among banks' customers in Yemen, employing SEM. The findings of this study showed that PE, EE, SI, trust, and awareness of UTAUT variables were significant predictors of IB adoption by banks' customers in Yemen. Furthermore, the elements of compatibility were found to be not significant for IB adoption. This study employed the UTAUT theory that accounts for the use of the united model within the technology adoption behaviour. In addition, this study presents the role of age and experience as moderating effects between UTAUT factors and intention to adopt IB among bank customers in Yemen. As stated earlier, this study focused on examining the applicability of UTAUT theory to identify and determine the variables which influence the adoption of IB services among banks' users in Yemen.

The main contribution of this research is statistically validation the factors UTAUT variables performance expectancy, effort expectancy, trust, and awareness are significantly influence banks customers to use IB in Yemen. In addition, most existing studies have been carried out in the context of developed countries meanwhile studies in similar topics in developing countries particularly Yemen is still scarce. This is because the IB technology and e-banking in Yemen is still mature since it is influenced by cultural settings in which people favor face-to-face dealings and also due to the low internet access of the Internet in Yemen.
Finally, this study certainly added to the existing knowledge to understand the acceptance and adoption of IB technology from the context of Yemen as a developing country through the use of unified theory (UTAUT) with modified variables (trust and awareness). The overall findings gave insights into the current state of IB use, adoption, and acceptance by banks' customers in Yemen and the factors hindering their adoption of the online IB services.

\section{REFERENCES}

[1] Abbad, M. M. (2013). E-banking in Jordan. Behaviour \& Information Technology, 32(7), 681-694.

[2] Al-Majali, M. M. (2011). The antecedents of internet banking service adoption in Jordan: using decomposed theory of planned behavior (Doctoral dissertation, Universiti Utara Malaysia).

[3] Al-Shbiel, S.O., \& Ahmad, M.A. (2016). A Theoretical Discussion of Electronic Banking in Jordan by Integrating Technology Acceptance Model and Theory of Planned Behavior. International Journal of Academic Research in Accounting Finance and Management Sciences, 6(3), 272-284

[4] Awwad, M. S., and Al-Majali, S. M. (2015). Electronic library services acceptance and use: an empirical validation of unified theory of acceptance and use of technology. TheElectronic Library, 33(6), 1100-1120.

[5] Chiou, J. S., \& Shen, C. C. (2012). The antecedents of online financial service adoption: the impact of physical banking services on Internet banking acceptance. Behaviour $\quad \&$ Information Technology, 31(9), 859-871. 
[6] Chou, S. Y., \& Barron, K. (2016). Employee voice behavior revisited: its forms and antecedents. Management Research Review, 39(12), 1720-1737.

[7] De Sena Abrahão, R., Moriguchi, S. N., and Andrade, D. F. (2016). Intention of adoption of mobile payment: An analysis in the light of the Unified Theory of Acceptance and Use of Technology (UTAUT). RAI Revista de Administração e Inovação, 13(3), 221-230.

[8] Fornell, C., \& Larcker, D. F. (1981). Evaluating structural equation model with unobservable variables and measurement error. Journal of Marketing Research $18(1), 39-50$

[9] Gupta, D., \& Kamilla, U. (2014). Cyber Banking in India: A Cross-Sectional Analysis Using Structural Equation Model. IUP Journal of Bank Management, 13(2).

[10] Hair, J. F., Anderson, R. E., Black, W. B., \& Tatham, R. L. (2010). Multivariate Data Analysis: Prentice Hall.

[11] Haque, A., Osman, J., \& Ismail, A. Z. (2009). Factor influences selection of Islamic banking: a study on Malaysian customer preferences. American Journal of Applied Sciences, 6(5), 922.

[12] Hew, J. J. (2017). Hall of fame for mobile commerce and its applications: A bibliometric evaluation of a decade and a half (2000-2015). Telematics and Informatics, 34(1), 43-66.

[13] Hew-Butler, T., Rosner, M. H., Fowkes-Godek, S., Dugas, J. P., Hoffman, M. D., Lewis, D. P. ... \& Roberts, W. O. (2015). Statement of the third international exercise-associated hyponatremia consensus development conference, Carlsbad, California, 2015. Clinical Journal of Sport Medicine, 25(4), 303-320.

[14] Huy, L., Rowe, F., Truex, D., \& Huynh, M. (2012). An empirical study of determinants of ecommerce adoption on SMEs in Vietnam: An empirical study. Journal of Global Information Management, 20.

[15] Jayawrdhena, C., \& Foly, P. (2000). Changes in the banking sector-the case of Internet banking in the UK. Internet research: Electronic Network application and policy, 10(1), 19-30.

[16] Kesharwani, A., \& Tripathy, T. (2012). Dimensionality of perceived risk and its impact on Internet banking adoption: An empirical investigation. Services Marketing Quarterly, 33(2), 177-193.

[17] Khrewesh, A. H. (2011). E-banking adoption model in Paleastine. Najah National University of graduate studies master, 12(7), 145-157.

[18] Lee, K. S., \& Kim, S. Y. (2007). Factors influencing the adoption behavior of mobile banking. A South Korean perspective. Journal of Internet Banking and Commerce, $12(2), 1-9$.

[19] Montazemi, A. R., \& Qahri-Saremi, H. (2015). Factors affecting adoption of online banking: A meta-analytic structural equation modeling study. Information \& Management, 52(2), 210-226.

[20] Nasri, W. (2011). Factors influencing the adoption of Internet banking in Tunisia. International Journal of Business and Management, 6(8), 143-159.

[21] Nour, K. M. (2002). ICT adoption in small and medium enterprises; An empirical evidence of service sector in
Malaysia. International Journal of business and Management, 4(2), 1-19.

[22] Parker, C., \& Castleman, T. (2007). New directions for research on SME-eBusiness: insights from an analysis of journal articles from 2003-2006. Journal of information systems and small business, 1(1), 21-40.

[23] Rotchanakitumnuai, S., \& Speece, M. (2007). Barriers to Internet banking adoption, qualitative study among corporate customers in Thailand. International Journal of bank Marketing, 21(6), 321-323.

[24] Sathye, M. (1999). Adoption of Internet banking by Australian consumer: An empirical investigation. International Journal of Bank Marketing, 17(7), 324-334.

[25] Schumacher, R. E., \& Lomax, R. G. (2004). A beginner's guide to structural equation modeling. Lawrence Erlbaum Associates, Inc., Mahwah, NJ.

[26] Shiels, H., McIvor, R., \& O'Reilly, D. (2003). Understanding the implications of ICT adoption: insights from SMEs. Logistics Information Management, 16(5), 312-326.

[27] Shih, Y., \& Fang, K. (2004). The use of decomposed theory of planned behavior to study Internet banking in Taiwan. Internet research, 14(3), 210-231.

[28] Suzanne Harrison, T., Peter Onyia, O., \& K. Tagg, S. (2014). Towards a universal model of internet banking adoption: initial conceptualization. International Journal of Bank Marketing, 32(7), 647-687.

[29] Teo, T., and Noyes, J. (2014). Explaining the intention to use technology among preservice teachers: a multi-group analysis of the Unified Theory of Acceptance and Use of Technology. Interactive Learning Environments, 22(1), 51-66

[30] Tsourela, M., and Roumeliotis, M. (2015).The moderating role of technology readiness, gender, and sex in consumer acceptance and actual use of Technologybased services. The Journal of High Technology Management Research, 26(2), 124-136.

[31] Venkatesh, V., \& Zhang, X. (2010). Unified theory of acceptance and use of technology: US vs. China. Journal of Global Information Technology Management, 13(1), 5-27.

[32] Venkatesh, V., Morris, M., \& Davis, G. (2003). User acceptance of information technology towards a unified view. MIS Quarterly: Management Information System, 27(2), 425-478.

[33] Venkatesh, V., Thong, J. Y., \& Xu, X. (2012). Consumer acceptance and use of information technology: extending the unified theory of acceptance and use of technology. MIS quarterly, 36(1), 157-178.

[34] Yousafzai, S. Y., Foxall, G. R., \& Pallister, J. G. (2010). Explaining internet banking behavior: theory of reasoned action, theory of planned behavior, or technology acceptance model?. Journal of applied social psychology, 40(5), 1172-1202.

[35] Zuiderwijk, A., Janssen, M., \& Dwivedi, Y. K. (2015). Acceptance and use predictors of open data technologies: Drawing upon the unified theory of acceptance and use of technology. Government information quarterly, 32(4), 429-440. 